\title{
ON THE ISSUES OF PROVISION OF DRUG AID AT THE PRIMARY LEVEL OF MEDICAL ASSISTANCE
}

10.36740/WLek202010115

\author{
Vasyl V. Kruchanytsia, Vasyl V. Skryp, Ivan S. Myroniuk, Hennady 0. Slabkiy \\ UZHOROD NATIONAL UNIVERSITY, UZHHOROD, UKRAINE
}

\begin{abstract}
The aim: Establish the types of narcological care to be provided at the primary level, develop a functional and organizational model of anti-narcotic activity of general practitioners/ family doctors and an algorithm for its integration at the primary level.

Materials and methods: Determination of types of anti-narcotic activity of GPs/family doctors was carried out expertly. The experts were 36 health care providers, doctors and alcohol abusers. The experts evaluated the proposed activities on a 10 point scale: full support - 10 points, and total ineligibility - 0 points. Expert opinion confidentiality saved. The bibliosemantic method and the method of structural-logical analysis were used in the work. The statistical method was used for statistical processing of the obtained results. Results: The list of types of medical care is grounded and the functional-organizational model of anti-narcotic activity of general practitioners-family doctors is developed, as well as the algorithm of integration into the primary level of complex anti-narcotic medical care to the population and the motivational mechanisms for the employees of primary level are offered to encourage them to the anti-narcotics activities.

Conclusions: implementation of the proposed innovations will increase the availability and effectiveness of anti-narcotic activities at the local level.
\end{abstract}

KEY WORDS: psychoactive substances, prevention, medical care, family doctor

Wiad Lek. 2020;73(10):2188-2192

\section{INTRODUCTION}

Psychoactive substances are the leading risk factors that take the lead in influencing the global burden of disease in most countries of the world [1]. According to WHO, illicit drug and alcohol use is a causative factor of more than 200 illnesses and traumas. According to figures DALY about $5.1 \%$ of the global burden of disease and injury in the world due to alcohol consumption. The Global Burden of Diseases, Injuries, and Risk Factors study (2010) [2] showed that, over the period 1990-2010, the loss of healthy life years as a result of alcohol consumption increased by $32 \%$. It should be noted that drug and alcohol use leads to death and disability at earlier stages of human life [3]. Alcohol and drug abuse goes beyond the physical and psychological health of people with addiction $[4,5]$. It seriously affects the well-being of society, the health and quality of life of others [6].

Introduction of modern forms of prevention of dependence of the population on the use of psychoactive substances (PASs) and providing the population with accessible medical assistancein the conditions of health care reform in Ukraine, when the general practitioner-family doctor (GPs/ FD) becomes the first contact doctor and determines the medical route patient $[7,8]$ is an extremely important task.

\section{THE AIM}

Establish the types of narcological care to be provided at the primary level, develop a functional and organizational model of anti-narcotic activity of GPs and family doctors and an algorithm for its integration at the primary level.

\section{MATERIALS AND METHODS}

Determination of types of anti-narcotic activity of GPs/ family doctors was carried out expertly. The experts were 3 doctors of medicine and 5 philosophy doctors in the specialty «social medicine», 5 organizers of health care of the highest qualification category, 7 doctors-narcologists and 7 general practitioners/family doctors of the first and higher qualification category, 5 persons who alcohol abuse, 4 representatives of local governments. The experts evaluated the proposed activities on a 10 point scale: full support - 10 points, and total ineligibility - 0 points. Expert opinion confidentiality saved.

The bibliosemantic method and the method of structural-logical analysis were used in the work. The statistical method was used for statistical processing of the obtained results.

\section{RESULTS}

In the first stage of the research, according to the set goal, using the expert method, the types of anti-narcotic activity of general practitioners/family doctors were identified at the current stage of development of the health care system of Ukraine. 
Table I. List of types of anti-narcotic activities of GPs/family doctors (points)

\begin{tabular}{|c|c|}
\hline Activity & Points \\
\hline Community outreach on anti-narcotic and anti-alcohol issues & 10,0 \\
\hline Family outreach on anti-narcotic and anti-alcohol issues & 10,0 \\
\hline Individual informational and educational work on anti-narcotic and anti-alcohol topics at the individual level & $9,9 \pm 0,2$ \\
\hline Counseling on anti-narcotic and anti-alcohol topics with groups at increased risk of psychoactive substance use & $9,8 \pm 0,2$ \\
\hline Information and educational work on anti-drug and anti-alcohol subject in schools & $9,5 \pm 0,3$ \\
\hline Screening for early detection of substance abusers & $9,6 \pm 0,2$ \\
\hline Organization of the school of health «Life without addictions» & $9,4 \pm 0,3$ \\
\hline Establishment of psycho-rehabilitation outpatient centers at work or at family outpatient clinics & $9,8 \pm 0,2$ \\
\hline $\begin{array}{l}\text { Collaboration with the public health system and educational institutions to provide «useful employment» to the young } \\
\text { people who are studying }\end{array}$ & $8,9 \pm 0,8$ \\
\hline Creation of substitution maintenance therapy sites based on family outpatient clinics & $9,7 \pm 0,2$ \\
\hline Dispensary monitoring of alcohol abusers under a program developed in conjunction with a physician narcologist & $4,8 \pm 1,1$ \\
\hline A cross-sectoral approach to community-based anti-narcotics & $9,1 \pm 0,6$ \\
\hline Treatment of the users of psychoactive substances program, developed in conjunction with narcologists & $4,2 \pm 1,1$ \\
\hline Involvement with the anti-narcotic activities of the church & $9,4 \pm 0,3$ \\
\hline Psychological support for members of the families of persons who use psychoactive substances & $8,5 \pm 0,9$ \\
\hline
\end{tabular}

The results of the experts' evaluation are presented in Table I.

The analysis of the results of the examination showed that the following types of anti-narcotic activities of general practitioners-family doctors were obtained by the independent experts: all kinds of information and educational activities including the establishment of school of health «Life without addictions» (10 points), creating psycho-rehabilitation outpatient centers in the workplace or on the basis of family clinics $(9,8 \pm 0,2)$, creation of a site of substitution maintenance therapy (SMT) (9.7 \pm 0.2 ), screening for early detection of substance abusers $(9.6 \pm 0.2)$, cross-sectoral approach to community-based anti-narcotic activity $(9.1 \pm 0,6)$, including involvement in such work of the church $(9,4 \pm 0,3)$.

The experts rated the lowest points the following types of anti-narcotic activities of general practitioners/family doctors as proposed for the evaluation: treatment of persons using psychoactive substances under a program developed in conjunction with a physician-narcologist $(4.2 \pm 1.1)$ and dispensary supervision of persons using psychoactive drugs substances according to a program developed in conjunction with a physician-narcologist $(4.8 \pm 1.1)$.

Anti-narcotic activities of general practitioners/family doctors should be carried out (depending on the direction of activity) on a cross-sectoral basis in cooperation with authorities, local community, non-governmental organizations, law enforcement agencies, health care institutions in which specialized medical care is provided, religious institutions and be directed not only at high-risk and substance-use individuals, but also at their close environment including family, work and informal "friends".

The key idea of the proposed list of anti-narcotic activities of general practitioners/family doctors is a consistent solution to the state priority of improving the effectiveness of preventive anti-narcotic measures and ensuring the availability and quality of medical care for persons who use psychoactive substances and abuse alcohol in critical situations and for those who have made the decision to get rid of this negative habit.

On the basis of the results obtained during the expert evaluation, a functional and organizational model of anti-narcotic activity of general practitioners-family doctors at the level of primary health care (PHC) was developed, which is presented in Fig. 1.

According to this model, the target groups of anti-narcotic effects of GPs/family doctors are: the general population, high-risk groups of psychoactive substance users, people who use psychoactive substances, close environment of people who use psychoactive substances.

The central element of the developed model is a general practitioner/ family doctor who provides a set of organizational, preventive, curative, rehabilitation and wellness measures to all target groups of the attached population.

For the purpose of implementation and effectiveness of the proposed functional-organizational model of anti-narcotic activity of GPs/family doctors, we have developed an algorithm for its introduction into the health care system of Ukraine, which provides the following.

The first stage. Acquisition by GPs - family doctors and family nurses of the necessary competencies for carrying out anti-narcotic work and preparation of material-technical and methodological base of family outpatient clinics for this work.

The second stage. Development of a single local protocol of anti-narcotic actions of health care workers at the administrative unit level. Communication with the target population. 


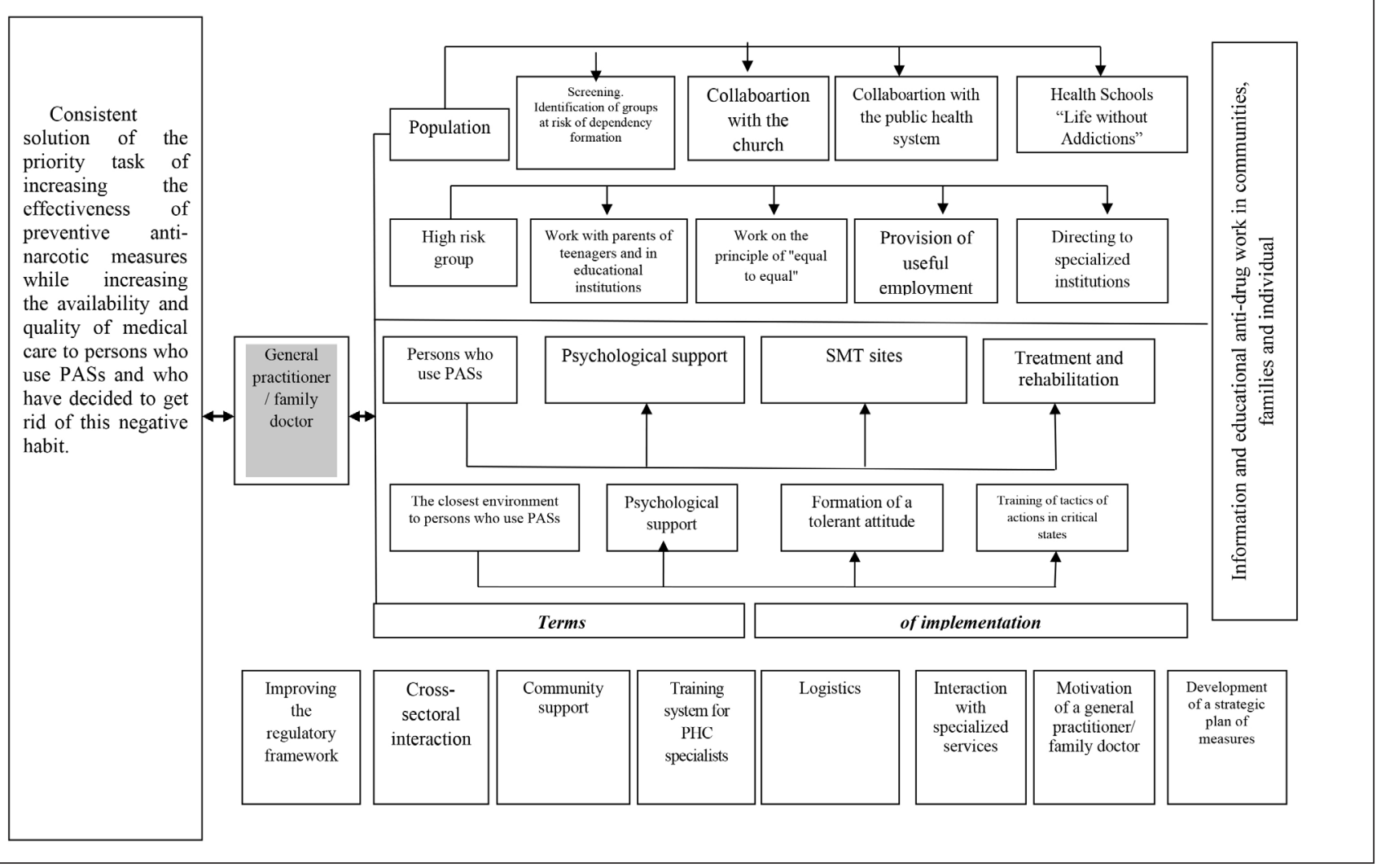

Fig. 1. Functional-organizational model of anti-narcotic activity of general practitioners-family doctor

The third stage. Preparation and approval of a community-based cross-sectoral anti-narcotics plan. Communication with the target population.

The fourth stage. Preparation of a family outpatient clinic and licensing for substitution maintenance therapy for injecting drug users. Developing mechanisms of motivation and local incentives for primary care health professionals to engage them in preventive anti-narcotic work and provide medical assistance to people who use psychoactive substances. Communication with the target population.

The fifth, permanent, stage. Integrated preventive anti-narcotic work and provision of medical assistance to people who use psychoactive substances at primary level. Communication with the target population. Monitoring and evaluation of the effectiveness of this section of activity.

A special place in the developed model is the creation of substitution therapy sites based on family outpatient clinics. According to the order of the Ministry of Health of Ukraine dated March 27, 2012 No. 200 "On Approval of the Procedure for Conducting Substitute Maintenance Therapy for Patients with Opioid Addiction", registered at the Ministry of Justice of Ukraine on June 5, 2012 under No. $889 / 21201$, only a doctor-narcologist is authorized to decide on the onset of SMT. This involves close collaboration between the primary care unit and the narcological service.

Paragraph 15 of the said Procedure for the SMT establishes that the SMT is conducted by a doctor with a qualification as a narcologist, or a doctor of another qualification (in our case, a general practitioner/family doctor) who has undergone a course of thematic improvement. The authority of a general practitioner/family doctor, in accordance with paragraph 18 of the Procedure for SMT, is to adjust the dosage of the drug in accordance with the complaints and the patient's condition.

Therefore, after the appointment of SMT by a narcologist, the patient is referred to the SMT offices in family outpatient clinics at the place of residence to receive the indicated therapy.

In accordance with the requirements of paragraphs 4 and 5 of the Drug Trafficking Order at the Primary Health Care Center, a responsible person from among the employees of the institution shall be appointed, who shall be entrusted with the functions of receiving, storing, transporting, purchasing, releasing, using, record keeping of drugs, psychotropic substances and precursors.

General practitioners/family physicians should organize the operation of the SMT site in accordance with the methodological recommendations approved by the order of the Ministry of Health of Ukraine of November 10, 2008 No. 645 "On approval of the methodological recommendations" Substitute maintenance therapy in the treatment of opioid addiction syndrome".

When creating SMT sites based on family outpatient clinics, their staffing lists do not increase, and SMT provision is a function of the GP and family nurse with a clear separation of functions between them and the use of motivational mechanisms to encourage them in this activity.

We recommend using the following financial (economic) and moral incentives. 
Incentives of direct financial nature: wage allowances, bonuses, additional payment for each service provided, additional paid leave;

Incentives not of direct financial nature: payment for various forms of advanced training;

Incentives of a moral nature: bringing to the Board of Honor a health care institution and public gratitude at the meeting of the team (letters and souvenirs), etc.

\section{DISCUSSION}

Functional-organizational model of anti-narcotic activity of GPs/family doctors is based on a new organizational system of providing primary and secondary medical care to the population using:

1) existing elements of the health care system involved in providing the population with narcological assistance: narcological dispensaries, doctors - narcologists of central district and city hospitals;

2) existing components, but partly modified by functional optimization: a cross-sectoral approach at the community level, organization of the School of Health «Life without Addictions», development of information and methodological materials for the prevention of mental disorders and behavior due to alcohol and PASs consumption;

3) qualitatively new elements: sites of substitution maintenance therapy on the basis of family outpatient clinics, outpatient centers of psychosocial rehabilitation, fundamentally new measures for the prevention of psychoactive substance use by adolescents and young people to ensure their useful employment, screening for early detection of psychoactive substance abusers, involvement in the church's anti-narcotic activities, the integration of which with the pre-existing and functionally improved elements provided the model with new qualities with the attainment of the main goal of the study.

The proposed model of reforming the health care system at the regional level can only work effectively in a cross-sectoral approach, based on the interest of the united communities, employers, education system, social protection of the population, law enforcement, religious and public organizations in this process.

Thus, the structural basis of the model is the existing resources of the current health care system while providing a cross-sectoral approach to the prevention of mental disorders and behavior due to the use of psychoactive substances. Its implementation requires additional financial resources for training of medical personnel, creation of sites of substitution maintenance therapy, creation of conditions for providing useful employment of children and young people.

\section{CONCLUSIONS}

1. The list of types of anti-narcotic activities of general practitioners/family doctors is substantiated.

2. Functional-organizational model of anti-narcotic activity of general practitioners/family doctors has been developed.
3. The algorithm of integration into the primary level of complex anti narcotic medical care to the population is presented.

4. Motivation mechanisms for primary care workers for their encouragement in anti-narcotic activities are proposed.

\section{REFERENCES}

1. Upravlenie Organizatsii Ob'edinennyih Natsiy po narkotikam i prestupnosti, Vsemirnyiy doklad o narkotikah. [United Nations Office on Drugs and Crime, World Drug Report 2017]. 2017. (ISBN: 978-92-1148291-1, elSBN: 978-92-1-060623-3, United Nations publication, Sales No. E.17.XI.6) https://www.unodc.org/wdr2017/field/WDR_Booklet1_ Exsum_Russian.pdf

2. Institute for Health Metrics and Evaluation, Human Development Network, The World Bank. The Global Burden of Disease: Generating Evidence, Guiding Policy - Europe and Central Asia Regional Edition. Seattle, WA: IHME, 2013.

http://www.healthdata.org/policy-report/global-burden-diseasegenerating-evidence-guiding-policy-\%E2\%80\%93-europe-andcentral-asia

3. Kruchanytsia V.V. Smertnist naselennia Zakarpatskoi oblasti vnaslidok vzhyvannia alkoholiu [Population mortality due to alcohol consumption in the Transcarpathian region]. Ukraine. Nation's Health. 2015; 2(34):59-62. (UA)

4. Anderson P., Moller L., Galea G. Alcohol in the European Union. Consumption, harm and policy approaches. Copenhagen, Denmark: World Health Organization, 2012. http://www.euro.who.int/en/ publications/abstracts/alcohol-in-the-european-union.-consumption,harm-and-policy-approaches

5. Framework for alcohol policy in the WHO European Region. WHO Regional Office for Europe. Copenhagen, Denmark. 2006. http://www. euro.who.int/document/e88335.pdf

6. Chemerys N.M., Liubinets O.V. Medyko-sotsialni ploshchyny vzhyvannia alkoholvmistymykh napoiv sered studentskoi molodi [Medico-social aspects for drinking alcohol in student youth]. Ukraine. Nation's Health. 2018; 1(47):42-47. (UA)

7. Batsenko D., Brahinskyi P., Buchma M. Yak orhanizuvaty systemu nadannia pervynnoi medychnoi dopomohy na mistsevomu rivni [How to set up a system of primary care at the local level]. Ministerstvo okhorony zdorovia Ukrainy PU«Vpud, editor. Kyiv: TOV «Ahentstvo «Ukraina»; 2018.368 p. (UA)

8. Slabkiy H.0., Zozulia I.S., Zozulia A.I. Priorytetnyi rozvytok pervynnoi medyko-sanitarnoi dopomohy na zasadakh simeinoi medytsyny [Priority development of primary health care based on family medicine]. Simeina medytsyna. 2014;3 (53):25-27. (UA)

The work was performed within the framework of the Scientific Research Work "Scientific Support for Regional Health Care Reform" / Code 51A-2015, State Registration Number 0112U001923. (The work is performed within the working hours of the employees of the department).

\section{ORCID and contributionship:}

Vasyl V. Kruchanytsia 0000-0003-4893-5289

Vasyl V. Skryp 0000-0003-1440-5677

Ivan S. Myroniuk 0000-0003-4203-4447 ${ }^{E}$

Hennady O. Slabkiy 0000-0003-2308-7869 


\section{Conflict of interest:}

The Authors declare no conflict of interest

\section{CORRESPONDING AUTHOR}

\section{Hennady 0. Slabkiy}

Uzhorod National University

Narodna sq. 3, 88001, Uzhhorod, Ukraine

tel: +380501711648

e-mail: g.slabkiy@ukr.net

Received: 28.05 .2019

Accepted: 31.08 .2020

A - Work concept and design, B - Data collection and analysis, C - Responsibility for statistical analysis,

D-Writing the article, $\mathbf{E}$-Critical review, $\mathbf{F}$ - Final approval of the article 